\title{
Methanol consumption drives the bacterial chloromethane sink in a forest soil
}

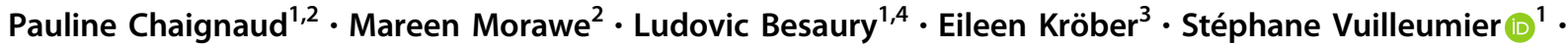 \\ Françoise Bringel $\mathbb{1}^{1} \cdot$ Steffen Kolb $\mathbb{1}^{3}$
}

Received: 16 February 2018 / Revised: 1 June 2018 / Accepted: 15 June 2018 / Published online: 10 July 2018

(c) The Author(s) 2018. This article is published with open access

\begin{abstract}
Halogenated volatile organic compounds (VOCs) emitted by terrestrial ecosystems, such as chloromethane $\left(\mathrm{CH}_{3} \mathrm{Cl}\right)$, have pronounced effects on troposphere and stratosphere chemistry and climate. The magnitude of the global $\mathrm{CH}_{3} \mathrm{Cl}$ sink is uncertain since it involves a largely uncharacterized microbial sink. $\mathrm{CH}_{3} \mathrm{Cl}$ represents a growth substrate for some specialized methylotrophs, while methanol $\left(\mathrm{CH}_{3} \mathrm{OH}\right)$, formed in much larger amounts in terrestrial environments, may be more widely used by such microorganisms. Direct measurements of $\mathrm{CH}_{3} \mathrm{Cl}$ degradation rates in two field campaigns and in microcosms allowed the identification of top soil horizons (i.e., organic plus mineral A horizon) as the major biotic sink in a deciduous forest. Metabolically active members of Alphaproteobacteria and Actinobacteria were identified by taxonomic and functional gene biomarkers following stable isotope labeling (SIP) of microcosms with $\mathrm{CH}_{3} \mathrm{Cl}$ and $\mathrm{CH}_{3} \mathrm{OH}$, added alone or together as the $\left[{ }^{13} \mathrm{C}\right]$-isotopologue. Well-studied reference $\mathrm{CH}_{3} \mathrm{Cl}$ degraders, such as Methylobacterium extorquens $\mathrm{CM} 4$, were not involved in the sink activity of the studied soil. Nonetheless, only sequences of the $с т и A$ chloromethane dehalogenase gene highly similar to those of known strains were detected, suggesting the relevance of horizontal gene transfer for $\mathrm{CH}_{3} \mathrm{Cl}$ degradation in forest soil. Further, $\mathrm{CH}_{3} \mathrm{Cl}$ consumption rate increased in the presence of $\mathrm{CH}_{3} \mathrm{OH}$. Members of Alphaproteobacteria and Actinobacteria were also ${ }^{13} \mathrm{C}$-labeled upon $\left[{ }^{13} \mathrm{C}\right]-\mathrm{CH}_{3} \mathrm{OH}$ amendment. These findings suggest that key bacterial $\mathrm{CH}_{3} \mathrm{Cl}$ degraders in forest soil benefit from $\mathrm{CH}_{3} \mathrm{OH}$ as an alternative substrate. For soil $\mathrm{CH}_{3} \mathrm{Cl}$ utilizing methylotrophs, utilization of several one-carbon compounds may represent a competitive advantage over heterotrophs that cannot utilize one-carbon compounds.
\end{abstract}

Electronic supplementary material The online version of this article (https://doi.org/10.1038/s41396-018-0228-4) contains supplementary material, which is available to authorized users.

\section{Françoise Bringel}

francoise.bringel@unistra.fr

$\bowtie$ Steffen Kolb

Kolb@zalf.de

1 Department of Microbiology, Genomics and the Environment, Université de Strasbourg, CNRS, GMGM UMR 7156, Strasbourg, France

2 Department of Ecological Microbiology, University of Bayreuth, Bayreuth, Germany

3 Microbial Biogeochemistry, RA Landscape Functioning, ZALF Leibniz Centre for Landscape Research, Müncheberg, Germany

4 Present address: UMR FARE 614 Fractionnement des AgroRessources et Environnement, Chaire AFERE, INRA, Université de Reims Champagne-Ardenne, Reims, France

\section{Introduction}

Chloromethane $\left(\mathrm{CH}_{3} \mathrm{Cl}\right)$ is the most abundant halogenated volatile organic compound (VOC) in the atmosphere and contributes substantially to destruction of stratospheric ozone $[1,2]$. Global emissions reach about $2.0 \pm 0.6 \mathrm{Tg} \mathrm{CH}_{3} \mathrm{Cl}$ per year [3,4]. Current knowledge also suggests that terrestrial $\mathrm{CH}_{3} \mathrm{Cl}$ emissions are mainly associated with biological activities of the aboveground part of plants and with white rot fungi in soil [5-7]. $\mathrm{CH}_{3} \mathrm{Cl}$ is produced upon burning of plant biomass, from methoxy groups of plant structural components such as lignin and pectin $[8,9]$. $\mathrm{CH}_{3} \mathrm{Cl}$ is also enzymatically produced by S-adenosylmethionine-dependent methylation of chloride [10]. Current estimates for the global sink are larger than the global source [3], to which forest soil could contribute as much as $1.0 \mathrm{Tg}$ per year [3,11]. Global budgets are still uncertain, as the nature of the biotic sink activity as well as its spatial and temporal variability are not known at the regional and global scale [12]. 
Net emissions of $\mathrm{CH}_{3} \mathrm{Cl}$ from terrestrial ecosystems are mitigated by soil and phyllosphere bacteria that utilize this VOC as a growth substrate [7, 13]. Such bacteria are aerobic methylotrophs, metabolically specialized for growth with one-carbon compounds [7]. The concentration of $\mathrm{CH}_{3} \mathrm{Cl}$ in the atmosphere is low (approx. $590 \mathrm{ppt}$ ). This suggests similar concentrations of $\mathrm{CH}_{3} \mathrm{Cl}$ in soils, although no experimental data are available to date $[3,14]$. Previous studies suggest that aerobic soil methylotrophs can utilize $\mathrm{CH}_{3} \mathrm{Cl}$ at environmentally relevant nanomolar to picomolar concentrations [15-20]. Such low concentrations likely do not yield sufficient energy for substantial bacterial growth with $\mathrm{CH}_{3} \mathrm{Cl}$. However, many known alphaproteobacterial $\mathrm{CH}_{3} \mathrm{Cl}$ degraders also grow with methanol $\left(\mathrm{CH}_{3} \mathrm{OH}\right)[13$, $21]$, and this is also true in situ for soil methylotrophs of a deciduous forest [22]. Abundance of methylotrophs in $\mathrm{O}$ and A soil horizons is high, and ranges from $10^{6}$ to $3 \times 10^{8}$ cells $\mathrm{g}_{\text {soil }}{ }^{-1}$, consistent with their frequent isolation from soils [23, 24].

Which organisms define the bacterial $\mathrm{CH}_{3} \mathrm{Cl}$ sink in soils is largely unknown at present. The only biochemically characterized pathway for $\mathrm{CH}_{3} \mathrm{Cl}$ utilization is the cmu pathway, characterized in detail for Methylobacterium extorquens CM4 [21]. It has been found in various $\mathrm{CH}_{3} \mathrm{Cl}$ degrading bacterial strains, including several strains from forest soil [7, 18, 25-27]. The chloromethane dehalogenase gene $с т и A$ has been used to detect $\mathrm{CH}_{3} \mathrm{Cl}$-degraders in various environments [15, 16, 18, 28-30]. Nonetheless, there is experimental and genomic evidence that the $\mathrm{cmu}$ pathway is not the only pathway for $\mathrm{CH}_{3} \mathrm{Cl}$ utilization [13].

We hypothesized that (a) top soil (i.e., organic layer $\left[\mathrm{O}_{\mathrm{f}}\right.$, $\mathrm{O}_{\mathrm{h}}$ ] plus A horizon) is the preferable habitat for $\mathrm{CH}_{3} \mathrm{Cl}$ degraders, and (b) that the as yet largely unknown $\mathrm{CH}_{3} \mathrm{Cl}$ bacterial sink in soils benefits from additional energy and carbon sources, such as $\mathrm{CH}_{3} \mathrm{OH}$ as a widespread methylotrophic growth substrate in soil [23, 24]. These hypotheses were tested for a European deciduous forest dominated by beech (Fagus sylvatica L.), and in a multi-treatment DNA stable isotope probing (SIP) laboratory experiment involving combinations of ${ }^{13} \mathrm{C}$-labeled and unlabeled $\mathrm{CH}_{3} \mathrm{OH}$ and $\mathrm{CH}_{3} \mathrm{Cl}$ amendment. Amplicon sequencing of $16 \mathrm{~S}$ rRNA, стиA, and mxaF/xoxF genes as relevant gene markers was employed to identify microorganisms potentially involved in the $\mathrm{CH}_{3} \mathrm{Cl}$ sink.

\section{Materials and methods}

Sampling site. Samples were collected in the natural forest reserve area Steigerwald located in South Germany $\left(49^{\circ} 37^{\prime}\right.$ $\mathrm{N}, 10^{\circ} 17^{\prime} \mathrm{O}$; sandy loam; Dystric Cambisol; pH of 4.6; mean annual temperature $7.5^{\circ} \mathrm{C}$; mean annual precipitation $725 \mathrm{~mm}$ ). Steigerwald forest has not been managed for at least 25 years and represents a quasi-pristine deciduous forest typical of Central Europe, i.e., predominance of European beech (Fagus sylvatica L.) with minor stocks of oak (Quercus robur L.) [31].

\section{Field closed-chamber measurements of $\mathrm{CH}_{3} \mathrm{Cl}$ consumption}

Eight closed top chambers were installed on-site at 12 am on 19 June 2013 and 20 August 2013. Air temperatures were $19{ }^{\circ} \mathrm{C}$ and $23^{\circ} \mathrm{C}$, respectively. The self-constructed stainless steel chambers had a total volume of $25.1 \mathrm{~L}(40 \mathrm{~cm}$ diameter; $20 \mathrm{~cm}$ height) and were equipped with an injection port. Chambers were spiked with $100 \mathrm{ppm}^{\mathrm{CH}} \mathrm{CH}_{3} \mathrm{Cl}$ [32] and gas samples were collected over a period of $180 \mathrm{~min}$ with gas-tight syringes, and stored in exetainers (Labco Limited, England) for subsequent analysis by gas chromatography (GC).

\section{First order rate constants of $\mathrm{CH}_{3} \mathrm{Cl}$-degradation}

Fresh beech leaves, dead leaf litter, soil horizons $\left(\mathrm{O}_{\mathrm{f}}, \mathrm{A}_{\mathrm{h}}\right.$, B), and rotting wood were investigated. For beech phyllosphere analysis, fresh beech leaves were sampled by cutting branches from trees and a pool of cut leaves were immediately used for experiments. Samples were taken on 20 August 2013 (8 locations per compartment pooled) and on 12 July 2016 (3 locations pooled), and transferred to duplicated gas-tight $125 \mathrm{~mL}$ serum bottles that were subsequently flushed with synthetic air (Rießner Gase $\mathrm{GmbH}$, Germany). $\mathrm{CH}_{3} \mathrm{Cl}$ (Rießner Gase $\mathrm{GmbH}$, Germany, purity $99.99 \%$ ) was injected to final concentrations of $60 \mathrm{ppb}$ or 200 ppm for samples taken on 20 August 2013 and 12 July 2016, respectively. Controls included a substrate-free control, a biological process control (amended with $20 \mathrm{mM}$ $\mathrm{KCN}$ to inhibit biological activity), and an anoxic control (headspace was pure $\mathrm{N}_{2}$ ). All treatments and controls were performed in triplicate. Gas samples were taken with gas-tight syringes and stored in $3 \mathrm{~mL}$, pre-evacuated exetainers (Labco 1tm, UK) for further analysis by gas chromatography.

\section{Soil microcosm set-up for DNA stable isotope probing (DNA SIP)}

Five samples from the upper soil layer within a $20 \mathrm{~m}$ circle, were taken on 20 August 2013, pooled, homogenized and sieved ( $2 \mathrm{~mm}$-mesh size). To stimulate $\mathrm{CH}_{3} \mathrm{Cl}$ consumption, sieved soil was aliquoted in batches of $500 \mathrm{~g}$ into sealed flasks, $\mathrm{CH}_{3} \mathrm{Cl}$ (Sigma Aldrich) added to the head space at a final concentration of $1 \%$, and incubated in $1 \mathrm{~L}$ glass flasks at $20^{\circ} \mathrm{C}$ in the dark. Mixing ratios of $\mathrm{CH}_{3} \mathrm{Cl}$ were followed by $\mathrm{GC}$ until added $\mathrm{CH}_{3} \mathrm{Cl}$ was consumed. Then, for each 
Table 1 Microcosm setup and carbon substrate amendment

\begin{tabular}{llll}
\hline $\begin{array}{l}\text { Carbon } \\
\text { source added }\end{array}$ & $\begin{array}{l}\text { Total carbon } \\
\text { added }(\mathrm{mM})^{\mathrm{a}}\end{array}$ & $\begin{array}{l}\text { Gas phase } \\
\text { amendment }\end{array}$ & $\begin{array}{l}\text { Liquid phase } \\
\text { amendment }\end{array}$ \\
\hline$\left.{ }^{\mathrm{c}}{ }^{13} \mathrm{C}\right]-\mathrm{CH}_{3} \mathrm{Cl}$ & 18 & {$\left[{ }^{13} \mathrm{C}\right]-\mathrm{CH}_{3} \mathrm{Cl}$} & $\mathrm{H}_{2} \mathrm{O}$ \\
{$\left[{ }^{13} \mathrm{C}\right]-\mathrm{CH}_{3} \mathrm{Cl}$} & 36 & {$\left[{ }^{13} \mathrm{C}\right]-\mathrm{CH}_{3} \mathrm{Cl}$} & $\mathrm{CH}_{3} \mathrm{OH}$ \\
and $\mathrm{CH}_{3} \mathrm{OH}$ & & $\mathrm{CH}_{3} \mathrm{Cl}$ & {$\left[{ }^{13} \mathrm{C}\right]-\mathrm{CH}_{3} \mathrm{OH}$} \\
$\mathrm{CH}_{3} \mathrm{Cl}$ and & 36 & & \\
{$\left[{ }^{13} \mathrm{C}\right]-\mathrm{CH}_{3} \mathrm{OH}$} & & - & {$\left[{ }^{13} \mathrm{C}\right]-\mathrm{CH}_{3} \mathrm{OH}$} \\
{$\left[{ }^{13} \mathrm{C}\right]-\mathrm{CH}_{3} \mathrm{OH}$} & 18 & $\mathrm{CH}_{3} \mathrm{Cl}$ & $\mathrm{H}_{2} \mathrm{O}$ \\
$\mathrm{CH}_{3} \mathrm{Cl}$ & 18 & $\mathrm{CH}_{3} \mathrm{Cl}$ & $\mathrm{CH}_{3} \mathrm{OH}$ \\
$\mathrm{CH}_{3} \mathrm{Cl}$ and & 36 & & \\
$\mathrm{CH}_{3} \mathrm{OH}$ & & - & $\mathrm{CH}_{3} \mathrm{OH}$ \\
$\mathrm{CH}_{3} \mathrm{OH}$ & 18 & - & $\mathrm{H}_{2} \mathrm{O}$ \\
$\mathrm{Control}^{18}$ & - & &
\end{tabular}

${ }^{a}$ Added per pulse ( 5 pulses in total)

${ }^{\mathrm{b}} \mathrm{A}$ volume of $6 \mathrm{~mL} \mathrm{CH} \mathrm{Cl}_{3} \mathrm{Cl}$ was added for each $\mathrm{CH}_{3} \mathrm{Cl}$ pulse. At each pulse, a total gas phase volume of $56 \mathrm{~mL}$ (air with or without $\mathrm{CH}_{3} \mathrm{Cl}$ ) was added to $500 \mathrm{~mL}$ flasks in order to maintain overpressure in the flasks

${ }^{c}$ Either $1 \mathrm{~mL}$ milliQ water or $216 \mathrm{mM} \mathrm{CH}_{3} \mathrm{OH}$ stock solution was added per pulse to each microcosm

microcosm of the DNA SIP experiment, $70 \mathrm{~g}$ activated soil was transferred to a $500 \mathrm{~mL}$ flask sealed with a Viton stopper. Eight different treatments were prepared, each performed in duplicates. Four treatments were amended with ${ }^{13} \mathrm{C}$-labeled substrates and four with unlabeled ${ }^{12} \mathrm{C}$ substrates. $\left[{ }^{13} \mathrm{C}\right]-\mathrm{CH}_{3} \mathrm{Cl}$ (Sigma Aldrich), $\left[{ }^{13} \mathrm{C}\right]-\mathrm{CH}_{3} \mathrm{Cl}$ together with unlabeled $\mathrm{CH}_{3} \mathrm{OH}$ (Campro Scientific), $\left[{ }^{13} \mathrm{C}\right]-$ $\mathrm{CH}_{3} \mathrm{OH}$ (Sigma Aldrich) together with unlabeled $\mathrm{CH}_{3} \mathrm{Cl}$, and $\left[{ }^{13} \mathrm{C}\right]-\mathrm{CH}_{3} \mathrm{OH}$ (Table 1). Control incubations were amended with equivalent amounts of unlabeled substrates, or left without amendment (Table 1). $\mathrm{CH}_{3} \mathrm{Cl}$ and/or $\mathrm{CH}_{3} \mathrm{OH}$ were amended as unlabeled or ${ }^{13} \mathrm{C}$-labeled isotopologue in 5 pulses over a period of 23 days (Fig. S1). $\mathrm{CH}_{3} \mathrm{Cl}$ and $\mathrm{CO}_{2}$ headspace mixing ratios were monitored by $\mathrm{GC}$, and amended again when $\mathrm{CH}_{3} \mathrm{Cl}$ was no longer detectable. After each pulse, 5 soil aliquots $(1 \mathrm{~g}$ each) per microcosm were retrieved and stored at $-80^{\circ} \mathrm{C}$ until further analysis.

\section{pH and gravimetric water content in soil samples}

$\mathrm{pH}$ was measured on sieved soil, before activation and after each substrate pulse using an InLab R422 $\mathrm{pH}$ electrode (InLab Semi-Micro; Mettler-Toledo, Gießen, Germany). Gravimetric soil moisture content was determined by weighing the soil before and after weight constancy following drying at $60{ }^{\circ} \mathrm{C}$.

\section{Quantification of $\mathrm{CH}_{3} \mathrm{Cl}, \mathrm{CO}_{2}$, and ${ }^{13} \mathrm{CO}_{2}$}

On 19 June 2013 and 20 August 2013, $\mathrm{CH}_{3} \mathrm{Cl}$ and $\mathrm{CO}_{2}$ mixing ratios were determined by GC (HP 5890 Series II,
Agilent) using a Porapak Q 80/100 column (Supelco, USA) and a helium-methane mixture (95:5) as the carrier gas. On 16 July $2016, \mathrm{CH}_{3} \mathrm{Cl}$ mixing ratios were determined by $\mathrm{ISQ}^{\mathrm{TM}}$ Quadrupole mass spectrometer (MS) coupled with TRACE ${ }^{\mathrm{TM}}$ Ultra gas chromatograph (GC) (Thermo Fisher Scientific, Massachusetts, USA). $\mathrm{CH}_{3} \mathrm{Cl}$ and $\mathrm{CO}_{2}$ mixing ratios were calculated by regression analysis based on a 5point calibration with standard mixing ratios of both gases. In the SIP experiment, GC MS analysis (Perkin-Elmer GC Clarus 600 system) was carried out as described previously [22]. Further Details of gas analysis methods are given in Supplemental Information.

\section{Nucleic acid extraction and RNA removal}

Nucleic acids from experimental replicates of all treatments and controls were extracted from each $0.5 \mathrm{~g}$ of soil when $\mathrm{CH}_{3} \mathrm{Cl}$ had been consumed after the third substrate pulse [33]. RNA was removed according to standard procedures including a treatment with RNAse followed by isopropanol precipitation (Supplemental Information). Recovered DNA was resuspended in DNAse-free water, quantified, and eventually stored at $-80^{\circ} \mathrm{C}$ until further processing through isopycnic centrifugation [22].

\section{DNA fractionation by isopycnic centrifugation}

Separation of the heavy $(\mathrm{H})$ and light (L) DNA in a cesium chloride gradient was described in detail previously [22, 34]. In brief, a cesium chloride gradient solution mixed with each RNA-free DNA was loaded into an ultracentrifugation tube, placed in a Vti 65.2 vertical rotor (Beckman Coulter, Germany) and centrifuged for $40 \mathrm{~h}$ at $177,000 \times g$ in a LE-70 ultracentrifuge (Beckman Coulter, Germany). DNA was harvested according to established procedures in 10 gradient fractions [22, 34]. The main four fractions of $\mathrm{H}$ and of $\mathrm{L}$ DNA were pooled and DNA was quantified [22] (Fig. S2a-b, Supplemental Information). DNA concentrations ranged between 0.3 and $3.0 \mathrm{ng} \mu \mathrm{L}^{-1}$ for $\mathrm{H}$ fractions, and 18.5 and $50.3 \mathrm{ng} \mu \mathrm{L}^{-1}$ for $\mathrm{L}$ fractions.

\section{PCR amplification, high-throughput sequencing, and data processing}

PCR amplification of the 16S rRNA gene, and of $\mathrm{CH}_{3} \mathrm{Cl}$ dehalogenase $\mathrm{CmuA}$ and methanol dehydrogenase $\mathrm{MxaF} /$ XoxF encoding genes are described in detail in Table 2, and in Table S2 (Supplemental Information). New primers were designed to detect a larger spectrum of genetic diversity using NGS sequencing both for cmuA (Table S2; Fig. S7) and mxaF / xoxF (Supplemental Information, Table S2, Fig S8). For sequencing analysis following PCR 
Table 2 Analyzed gene markers and amplicon characteristics

\begin{tabular}{|c|c|c|c|c|c|c|c|c|}
\hline $\begin{array}{l}\text { Gene } \\
\text { marker }\end{array}$ & Function & PCR Primer & Sequence $\left(5^{\prime}-3^{\prime}\right)^{\mathrm{a}}$ & $\begin{array}{l}\text { Amplicon } \\
\text { size (bp) }\end{array}$ & $\begin{array}{l}\text { SNP/ } \\
\text { OTU }^{\mathrm{b}}\end{array}$ & $\begin{array}{l}\text { Total } \\
\text { OTUs }\end{array}$ & $\begin{array}{l}\text { Labeled } \\
\text { OTUs }^{d}\end{array}$ & Reference \\
\hline \multirow{2}{*}{$\begin{array}{l}16 \mathrm{~S} \\
\text { rRNA } \\
\text { gene }\end{array}$} & \multirow{2}{*}{$\begin{array}{l}\text { Ribosomal small } \\
\text { subunit RNA }\end{array}$} & 341 for & CCTACGGGNGGCWGCAG & \multirow[t]{2}{*}{464} & \multirow[t]{2}{*}{9} & \multirow[t]{2}{*}{117} & \multirow[t]{2}{*}{5} & {$[60]$} \\
\hline & & 785/805rev & GACTACHVGGGTATCTAATCC & & & & & {$[61]$} \\
\hline \multirow[t]{2}{*}{ стиА } & \multirow{2}{*}{$\begin{array}{l}\text { chloromethane } \\
\text { methyltransferase }\end{array}$} & cmuAf422 & GARGTBGGITAYAAYGGHGG & \multirow[t]{2}{*}{422} & \multirow[t]{2}{*}{38} & \multirow[t]{2}{*}{8} & \multirow[t]{2}{*}{5} & \multirow[t]{2}{*}{ This study } \\
\hline & & cmuAr422 & TCRTTGCGCTCRTACATGTCICC & & & & & \\
\hline \multirow{3}{*}{$\begin{array}{l}\operatorname{mxaF/} \\
x o x F^{\mathrm{e}}\end{array}$} & \multirow{3}{*}{$\begin{array}{l}\text { methanol } \\
\text { dehydrogenase }\end{array}$} & mdh1 & GCGGIWSCEAICTGGGGYT & \multirow[t]{3}{*}{430} & \multirow[t]{3}{*}{39} & \multirow[t]{3}{*}{6} & \multirow[t]{3}{*}{6} & \multirow[t]{3}{*}{ This study } \\
\hline & & $\operatorname{mdh} 2$ & GCGGIWSĞAICTGGGGYT & & & & & \\
\hline & & mdhR & GAASGGYTCSYARTCCATGCA & & & & & \\
\hline
\end{tabular}

${ }^{\mathrm{a} D e g e n e r a t e ~ b a s e ~ m i x t u r e s: ~ B ~(C, G, T), ~ H ~(A, C, T), ~ K ~(G, T), ~ N ~(A, C, G, T), ~ R ~(A, G), ~ S ~(G, C), ~ Y ~(C, T), ~ V ~(A, ~ C, ~ T), ~ W ~(A, T) . ~ I n o s i n e ~(I) ~ w a s ~ u s e d ~}$ instead of the $\mathrm{N}$ mixture [62] in some cases

${ }^{\mathrm{b}}$ Maximal Single Nucleotide Polymorphism (SNP) positions possible within an OTU

${ }^{c}$ Corresponding to the sum of OTUs detected in the 8 microcosms of the SIP experiment. Sequences were affiliated to the same OTU at cutoff values of 98,90 , and $80 \%$ sequence identity at the nucleotide level for $16 \mathrm{~S}$ rRNA gene, cmuA, and mxaF/xoxF amplicons, respectively

${ }^{\mathrm{d}}$ See Material and Methods for the criteria applied to define OTUs as 'labeled'

${ }^{\text {e}}$ Primer pairs allow to amplify both $m x a F$ and $x o x F$ types of methanol dehydrogenase (mdh) sub units Amplifications were performed with two different forward primers (mdh1, mdh2) in order to reduce primer degeneracy and improve PCR efficiency. Amplicons obtained with primers $\mathrm{mdh} 1 / \mathrm{mdhR}$ and $\mathrm{mdh} 2 / \mathrm{mdhR}$ were pooled before sequencing.

${ }^{\mathrm{f}}$ See Supplemental Information of Materials and Methods for details

amplification, briefly, a barcode oligonucleotide identifying sample origin was ligated to each PCR product. Equimolar pools of all libraries were assembled, and the resulting combined library was sequenced using Illumina MiSeq technology (LGC Genomics GmbH, Germany). Reads were assembled into contigs and analyzed using Mothur v.1.33.2 with default parameters (http://www.mothur.org/wiki/ MiSeq_SOP) [35]. 16S rRNA reads $<420$ or $>460 \mathrm{bp}$ were discarded. Reads were pre-clustered into groups of sequences with up to 2 nucleotide differences. Chimera sequences were removed with UCHIME [36]. Remaining sequences were assigned by naïve Bayesian taxonomic classification using the SILVA reference database. Sequences that could not be assigned to Bacteria and Archaea were excluded from further analysis. OTUs were defined at $98 \%$ sequence similarity. Raw reads of cmuA and $m x a F / x o x F$ amplicons with read lengths within 20 nucleotides of the expected amplicon length were clustered by USEARCH [37]. Sequences occurring only once in all libraries were considered artefactual and removed, but singletons within individual amplicon libraries were kept. Reads were clustered iteratively at progressively lower cutoff values, and the cut-off value at which the number of retrieved OTUs stabilized was selected [38]. These OTU sequences were compared against a gene-specific database generated from GenBank using BLAST (http://blast.ncbi. nlm.nih.gov) for identification. Taxonomic assignments of consensus sequences of each OTU were used to identify ${ }^{13} \mathrm{C}$-labeled gene OTUs.

\section{Identification of ${ }^{13} \mathrm{C}$-labeled OTUs}

Labeled OTUs were defined according to a previously reported protocol developed to minimize false positives in 'H DNA' fractions [22, 39]. The following criteria were applied to identify ${ }^{13} \mathrm{C}$-labeled OTUs: (1) OTU abundance in the 'heavy' fraction of a microcosm treated with ${ }^{13} \mathrm{C}$ labeled substrate higher than in the 'heavy' fraction of the corresponding microcosm treated with unlabeled substrate; (2) OTU abundance in the 'heavy' fraction higher than in the 'light' fraction; (3) OTU abundance in the 'heavy' fraction of the microcosm treated with ${ }^{13} \mathrm{C}$-labeled substrate $\geq 0.5 \%$; (4) OTU abundance difference between 'heavy' and 'light' fractions higher by at least $0.3 \%$ (a threshold that considers the variance of each OTU abundance). Moreover, a lower limit of 5\% was set for the labeling proportion (LP), (i.e., the relative frequency of a labeled OTU in a specific heavy fraction) of a given OTU to be considered as labeled [22].

\section{Statistical and phylogenetic analyzes}

Richness and Simpson diversity indices were determined using Mothur and PAST (http://folk.uio.no/ohammer/past). Relationships between sequence datasets in different DNA fractions and microcosms were investigated by twodimensional NMDS (non-metric multidimensional scaling) within Mothur, and visualized with Kaleidagraph (Synergy Software, Reading, PA, USA). Details on phylogenetic tree construction are given in figure legends. 
Fig. 1 Dissipation of added $\mathrm{CH}_{3} \mathrm{Cl}$ in forest soil. Closed top chambers applied onto soil at the Steigerwald forest sampling site were amended with $100 \mathrm{ppm}$ $\mathrm{CH}_{3} \mathrm{Cl}$ (color symbols, chambers 1-5) or incubated without supplementation (black symbols, triplicate controls) on a 19 June 2013 and b 20 August 2013
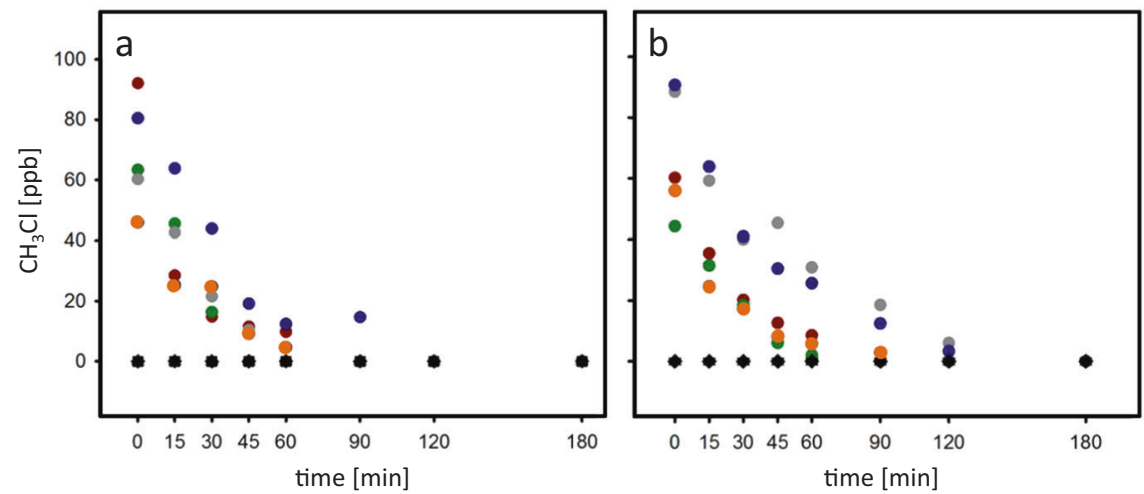

\section{Nucleotide sequence accession numbers}

Sequence datasets were deposited to the NCBI BioSample database under the study accession number SUB3319582.

\section{Results}

Localization of active $\mathrm{CH}_{3} \mathrm{Cl}$ consumption in different forest compartments. Two sampling campaigns were performed, with the second campaign aiming to verify and justify that top soil samples were indeed the most active in $\mathrm{CH}_{3} \mathrm{Cl}$ degradation, since only this horizon was selected to be assessed by SIP. Immediate consumption of $\mathrm{CH}_{3} \mathrm{Cl}$ was observed in two field site campaigns at the temperate deciduous forest Steigerwald (Fig. 1a, b). In contrast, no net $\mathrm{CH}_{3} \mathrm{Cl}$ emissions were detected from the forest floor $(<1 \mathrm{ppb}$ in chambers headspace). This strongly suggested that the investigated forest top soil represents a major sink for atmospheric $\mathrm{CH}_{3} \mathrm{Cl}$ at the forest ecosystem level.

Results from lab-scale microcosms suggest that net $\mathrm{CH}_{3} \mathrm{Cl}$ consumption was primarily due to biological activity. Indeed, $\mathrm{CH}_{3} \mathrm{Cl}$ consumption was not observed in microcosms that were treated with $\mathrm{KCN}$ (Fig. 2a-e). $\mathrm{O}_{\mathrm{f}}$ and $\mathrm{A}_{\mathrm{h}}$ horizons were the most active layers (Fig. 2b, c). Because no $\mathrm{CH}_{3} \mathrm{Cl}$ consumption was detected under anoxic conditions (data not shown), top soil aerobic microorganisms likely represent the active sink for $\mathrm{CH}_{3} \mathrm{Cl}$ (Fig. 2b). Results obtained for the phyllosphere of European beech were variable, as we detected substantial consumption of $\mathrm{CH}_{3} \mathrm{Cl}$ in 2013 only (Fig. 2e).

\section{Mineralization and assimilation of $\mathrm{CH}_{3} \mathrm{Cl}$ by the top soil microbial community}

As expected, a net increase in $\mathrm{CO}_{2}$ formation occurred in all microcosms in response to substrate amendment (Fig. S1a-c). A non-significant trend was observed towards larger $\mathrm{CO}_{2}$ release upon addition of $\mathrm{CH}_{3} \mathrm{OH}$ compared to $\mathrm{CH}_{3} \mathrm{Cl}$
(Fig. S1c). Rates of $\mathrm{CO}_{2}$ production were in the range of $0.2-0.3 \mathrm{mmol} \mathrm{g}_{\text {dry soil }}{ }^{-1} \mathrm{day}^{-1}$ for microcosms to which $\mathrm{CH}_{3} \mathrm{Cl}$ or $\mathrm{CH}_{3} \mathrm{OH}$ was added. No differences in $\mathrm{CO}_{2}$ release between microcosms to which labeled or unlabeled substrates were added were observed, confirming that different carbon isotopologues did not affect carbon metabolism ( $t$-test, $p>$ 0.10; Fig. S1). Uncertainties were large, but about $10 \mathrm{mM}$ $(20 \%)$ of the added $54 \mathrm{mM}$ of $\left[{ }^{13} \mathrm{C}\right]-\mathrm{CH}_{3} \mathrm{Cl}$ were converted to $\left[{ }^{13} \mathrm{C}\right]-\mathrm{CO}_{2}$ (Fig. S1). Hence, up to $80 \%$ of amended $\left[{ }^{13} \mathrm{C}\right]-\mathrm{CH}_{3} \mathrm{Cl}$ was assimilated into biomass. This rather high rate may be an overestimate, given measurement uncertainties and undetected losses by precipitation of carbonate. An nonsignificant increase in $\left[{ }^{13} \mathrm{C}\right]-\mathrm{CO}_{2}$ formation from labeled $\left[{ }^{13} \mathrm{C}\right]-\mathrm{CH}_{3} \mathrm{Cl}$ was observed when unlabeled $\mathrm{CH}_{3} \mathrm{OH}$ was also provided ( $t$-test, $p>0.10$; Fig. S1c). In the reverse case of microcosms amended with $\left[{ }^{13} \mathrm{C}\right]-\mathrm{CH}_{3} \mathrm{OH}$ together with unlabeled $\mathrm{CH}_{3} \mathrm{Cl}$, the increase in $\left[{ }^{13} \mathrm{C}\right]-\mathrm{CO}_{2}$ formation was slightly less. Moreover, $\mathrm{CH}_{3} \mathrm{OH}$ was mineralized to a larger extent than $\mathrm{CH}_{3} \mathrm{Cl}$ when added alone ( $t$-test, $p \leq 0.05$ ). Taken together, these observations suggest that microbial $\mathrm{CH}_{3} \mathrm{Cl}$ consumption activity is enhanced by $\mathrm{CH}_{3} \mathrm{OH}$.

\section{Overall microbial community response to amended substrates}

Based on three gene markers, amendment of substrates led to significant changes in microbial community composition, basing on statistical analyzes combining ${ }^{13} \mathrm{C}$-labeled and unlabeled phylotypes (Fig. S3a-c, Table S3, Tables 3 and 4). Combined with the observation that $\mathrm{CO}_{2}$ formation increased in amended microcosms (Fig. S1), this suggested increased growth of specific microorganisms with amended substrates.

\section{Diversity of ${ }^{13} \mathrm{C}$-labeled family-level OTUs based on the 16S rRNA gene}

A total of 117 family-level OTUs (90\% similarity) were detected (Table S1). Of these and across all four substrate treatments (Fig. 3a), several genera within five families 
Fig. 2 Dissipation of added $\mathrm{CH}_{3} \mathrm{Cl}$ in microcosms of forest compartments. First order rate constants [k] of $\mathrm{CH}_{3} \mathrm{Cl}$-amended microcosms of Steigerwald forest sampled on 20 August 2013 (circles) and on 12 July 2016 (diamonds). a Leaf litter $\left(2013, k=2.35 \mathrm{~h}^{-1} ; 2016, k=\right.$ $\left.0.19 \mathrm{~h}^{-1}\right)$; b $\mathrm{O}_{\mathrm{f}}$ horizon $(2013, k$ $=3.04 \mathrm{~h}^{-1} ; 2016, k=2.42 \mathrm{~h}$

$\left.{ }^{-1}\right)$; c $\mathrm{A}_{\mathrm{h}}$ horizon $(2013, k=$ $\left.6.93 \mathrm{~h}^{-1} ; 2016, k=2.00 \mathrm{~h}^{-1}\right)$; d B horizon $(2016, k=2.72)$; e fresh beech leaves $(2013, \mathrm{k}=$ $\left.2.76 \mathrm{~h}^{-1} ; 2016, \mathrm{k}=0.06 \mathrm{~h}^{-1}\right)$. Control experiments without amendment (triangles) or including $\mathrm{KCN}$ on top of $\mathrm{CH}_{3} \mathrm{Cl}$ to inhibit biological activity (squares) were also performed. $\mathrm{B}$ horizon was only measured in 2016
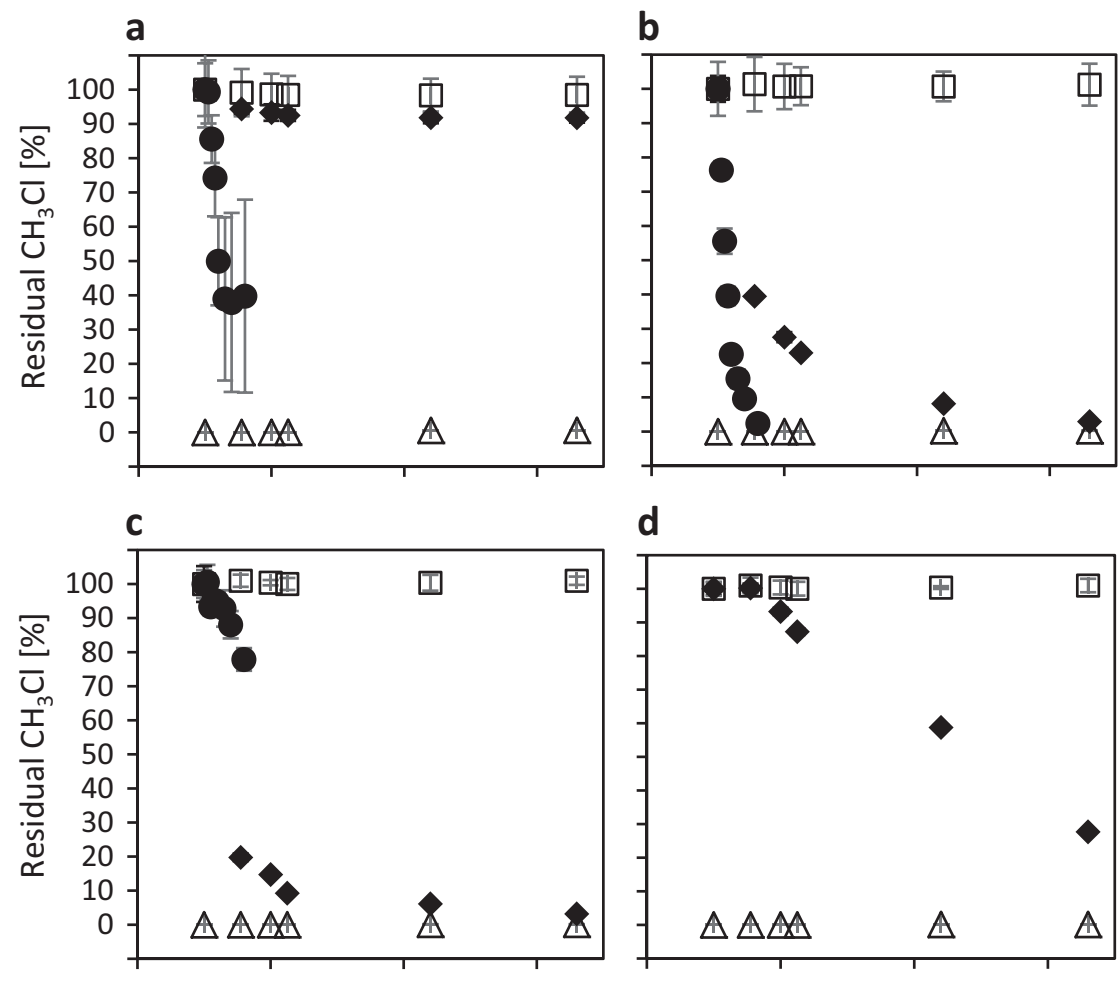

5 15 25 time [h]

Sample 2013

- Sample 2016

Control with KCN

$\triangle$ Control without $\mathrm{KCN} / \mathrm{CH}_{3} \mathrm{Cl}$ were identified that satisfied the criteria set for defining ${ }^{13} \mathrm{C}$-labeled OTUs (Fig. 3a): Beijerinckiaceae within Alphaproteobacteria, three families of Actinobacteria (Acidothermaceae, Pseudonocardiaceae, and Streptomycetaceae) and OTU108 $16 \mathrm{~S}$ within the TM7 phylum, recently renamed as Candidatus Saccharibacteria (Fig. S4) [40]. Methylovirgula, Acidothermus, and Streptomyces represented over $95 \%$ of the Beijerinckiaceae, Acidothermaceae, and Streptomycetaceae, respectively (Fig. 3a). In the microcosm amended with $\left[{ }^{13} \mathrm{C}\right]-\mathrm{CH}_{3} \mathrm{Cl}$, three of the five family-level OTUs (Acidothermaceae, Beijerinckiaceae, and Streptomycetaceae) represented about $80 \%$ of all labeled OTUs (Fig. 3a). In the microcosm amended with $\left[{ }^{13} \mathrm{C}\right]-$ $\mathrm{CH}_{3} \mathrm{OH}$, in contrast, mainly Beijerinckiaceae was labeled. The labeled Cand. Saccharibacteria-like OTU108 16 s and the Pseudonocardiaceae sp.-like OTU85 $16 \mathrm{~S}$ were both found at low abundance in all ${ }^{13} \mathrm{C}$-amended microcosms (Fig. 3a). All labeled OTUs differed from the closest type strains as well as from previously described $\mathrm{CH}_{3} \mathrm{Cl}$-degrading isolates (Fig. S4). Another interesting observation was that several other detected Actinobacteria, i.e. Gryllotalpicola, likely represent $\mathrm{CH}_{3} \mathrm{OH}$ utilizers based on labeling patterns (Fig. 3a, Fig S4).

\section{Diversity of $\mathrm{CH}_{3} \mathrm{Cl}$ utilizers based on $\mathrm{CmuA}$}

Chloromethane:cobalamin methyltransferase $c m u A$, the biomarker for $\mathrm{CH}_{3} \mathrm{Cl}$ consumption by the $\mathrm{cmu}$ pathway, was amplified with newly designed primers (Table S2). Eight OTUs were detected among which five satisfied the criteria defined for ${ }^{13} \mathrm{C}$-labeled OTUs (Table S3). Consensus sequences of these 8 OTUs were compared to known 
Fig. 3 Relative abundance of $\left[{ }^{13} \mathrm{C}\right]$-labeled phylotypes. a Bacterial 16S rRNA genes, b $c m u A$, and c mxaF/xoxF. Only microcosms exposed to $\left[{ }^{13} \mathrm{C}\right]-$ labeling are shown. Specific OTUs are indexed with corresponding gene markers (e.g., OTU108 $16 \mathrm{~S})$. Phylogenetic assignments are based on phylogenetic reconstructions (Fig. S3 [16S rRNA gene], Fig. S4 [mxaF/xoxF], and Fig. 4 [cmuA]). OTUs with $>0.5 \%$ relative abundance in the $\mathrm{H}$ fraction but $<5 \%$ labeling proportion were not considered as labeled. Unlabeled OTUs with relative abundance $<0.5 \%$ are not shown

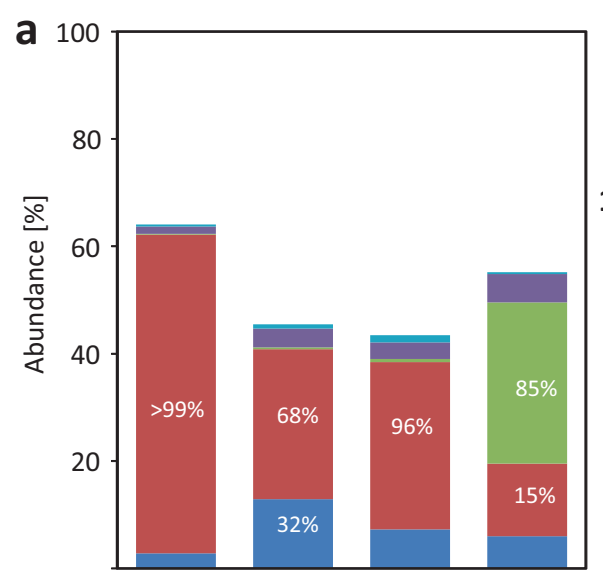

\section{S rRNA genes}

- OTU108 $_{165}$ Cand. Saccharibacteria

- 0 OTU85 $5_{165}$ Pseudonocardia (Actinobacteria)

- 0 OTU61 165 Gryllotalpicola (Actinobacteria)

- OTU12 ${ }_{165}$ Methylovirgula (Alphapreoteobacteria)

- OTU6 $_{165}$ Kineosporia (Actinobacteria)
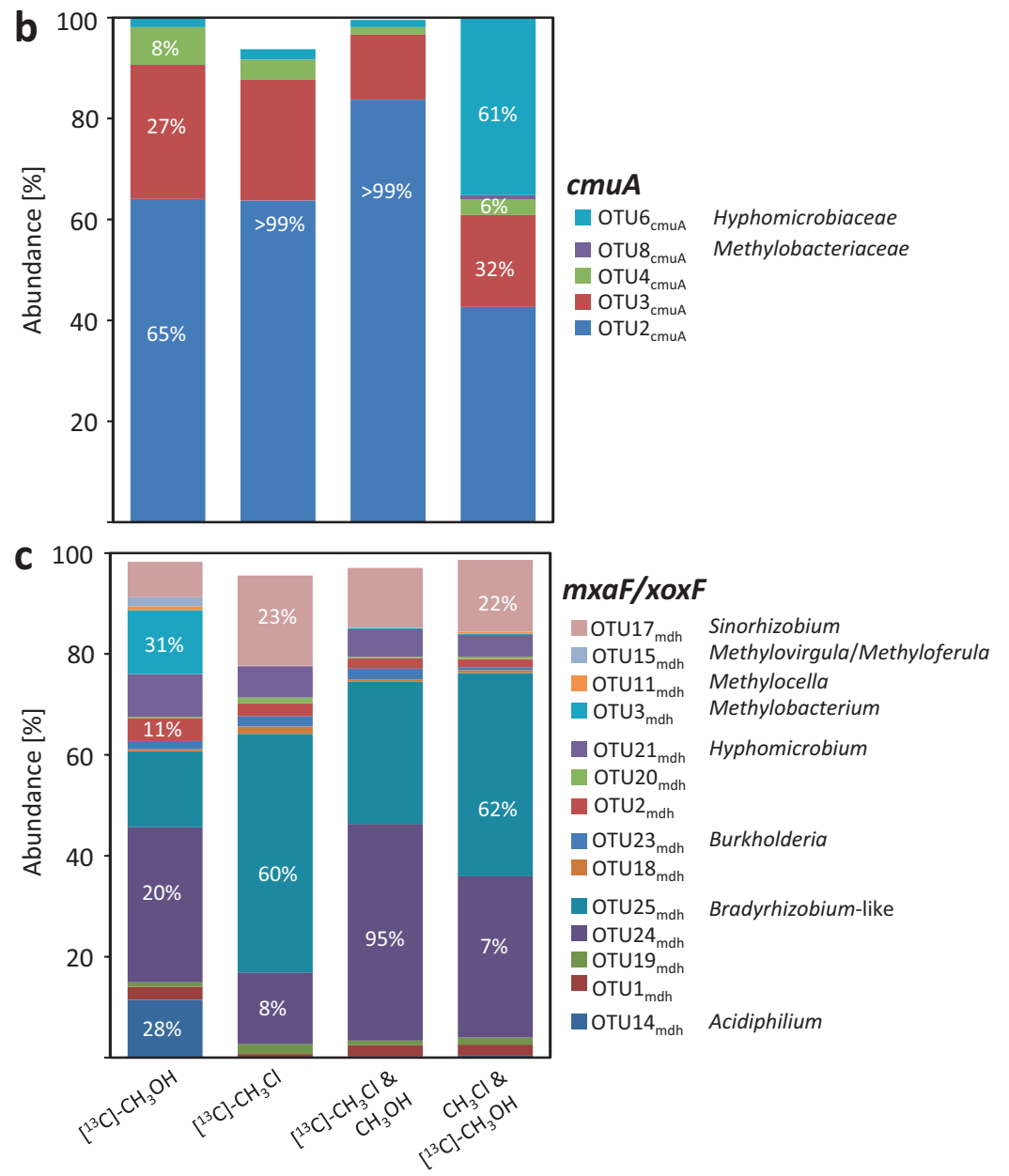

стиА of genome-sequenced cultivated strains, and of uncultivated OTUs identified in a previous SIP study of soil amended with $\left[{ }^{13} \mathrm{C}\right]-\mathrm{CH}_{3} \mathrm{Cl}$ [15]. The eight OTUs belonged to three distinct gene clusters (Fig. 4). Labeled OTUs were closely related to sequences of known $\mathrm{CH}_{3} \mathrm{Cl}$-degraders including Methylobacterium extorquens CM4 (>99 \% identity) or Hyphomicrobium sp. MC1, as well as with стиA sequences retrieved from a soil environment [15]. In the $\mathrm{CH}_{3} \mathrm{Cl}$ treatment, OTU2 $2_{\mathrm{cmuA}}$ and $\mathrm{OTU} 3_{\mathrm{cmuA}}$ were among the most dominant ${ }^{13} \mathrm{C}$-labeled OTUs. This labeling pattern was conserved in all ${ }^{13} \mathrm{C}$-labeled substrate treatments of our study (Fig. 3b). However, when methanol was the ${ }^{13} \mathrm{C}$-labeled substrate, an additional OTU6 ${ }_{\text {cmuA }}$ was detected (Fig. 3b). OTU6 cmuA $_{\text {as }}$ very similar to $\mathrm{cmuA}$ genotypes of reference $\mathrm{CH}_{3} \mathrm{Cl}$-degrading Hyphomicrobium strains (Fig. 4). All other ${ }^{13} \mathrm{C}$-labeled OTUs represented minor populations with closest similarity to $с т и A$ from Methylobacterium (Figs. 3b, 4). 


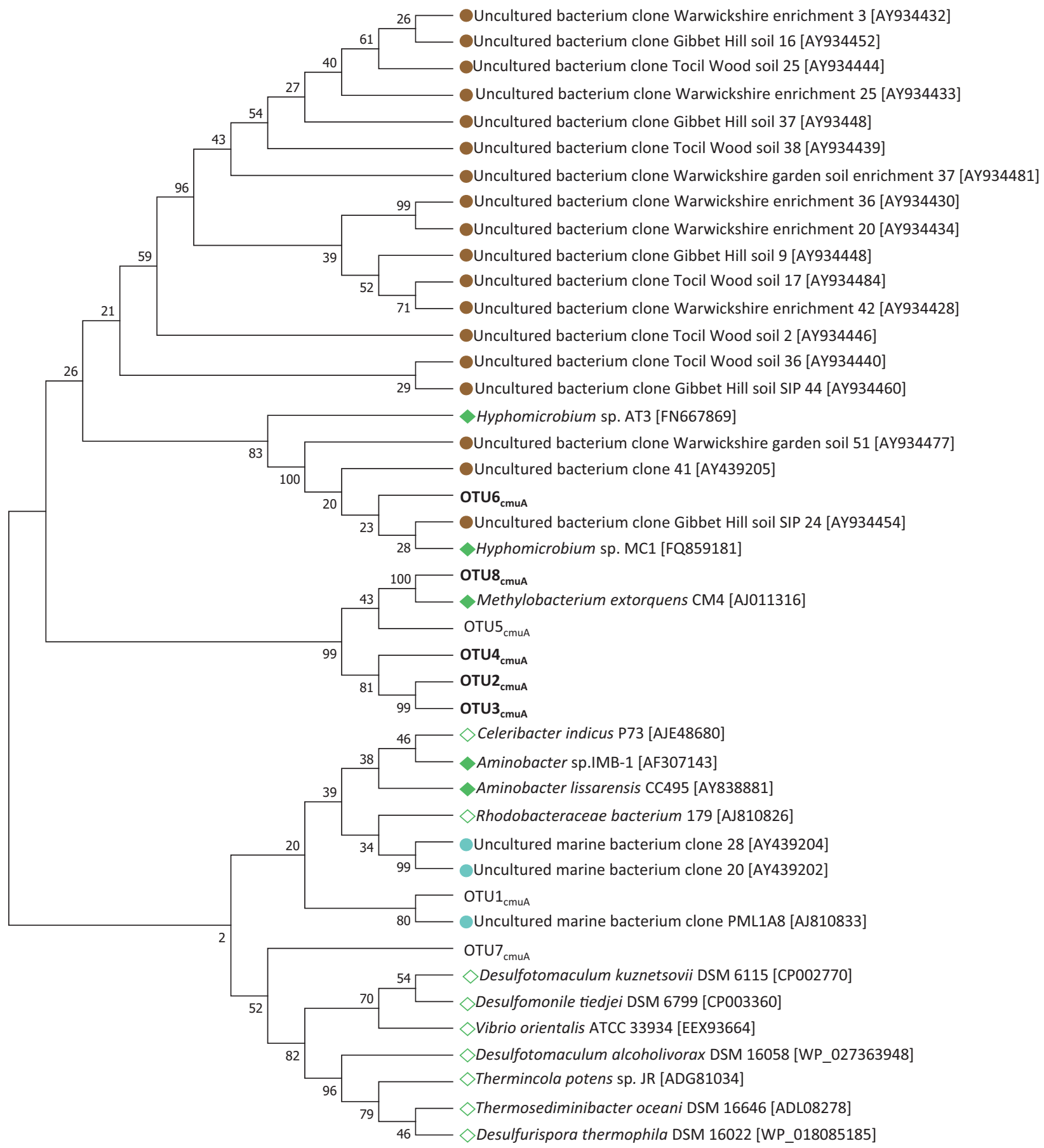

Fig. 4 Phylogenetic affiliations of detected стиA OTUs. A maximum likelihood phylogenetic tree was reconstructed from a 422 nt-long sequence alignment based on the Tamura-Nei model [59]. Bold, labeled стиA OTUs. Scale bar, 0.05 substitutions per site. Bootstrapping was performed with 1000 replicates. Reference sequences

\section{Diversity of methanol utilizers based on $m \times a F / x o x F$}

Two types of methanol dehydrogenase (mdh) are predominantly found in methanol utilizers, MxaFI and XoxF, both harboring a pyrroloquinoline quinone catalytic center from previous studies were included: characterized $\mathrm{CH}_{3} \mathrm{Cl}$-utilizing isolates (green diamonds); uncharacterized genome-sequenced isolates containing сти genes (green open diamonds); sequences detected by SIP in the marine environment (blue circles [30]) or in soil (brown circles [18])

[41]. Previously used mxaF/xoxF primers were biased against $x o x F$ [42]. Thus, we designed new $m d h$ primers targeting both types of MDH (Table 2 and S2; Fig. S8). A total of 15 distinct ${ }^{13} \mathrm{C}$-labeled $m d h$ OTUs were found, all but one $x$ xxF genes (Figs. 3c and S5). These OTUs were 
mostly affiliated to one of the canonical XoxF clades, i.e., XoxF5 [41]. The underrepresentation of other clades might had been effected by the design strategy of the primers (Fig. S8, Supplemental Information). Only OTU15 ${ }_{\text {mdh }}$ was closely similar to a $m x a F$ gene of Beijerinckiaceae (Fig. 3c and Fig. S5). Predominant ${ }^{13} \mathrm{C}$-labeled mxaF/xoxF OTUs associated with known $x o x F$ genes of Bradyrhizobium and Sinorhizobium were found in all four ${ }^{13} \mathrm{C}$-labeled substrate treatments. On the other hand, ${ }^{13} \mathrm{C}$-labeled mxaF/xoxF OTUs closely related with $x o x F$ genes from Acetobacteraceae (Acidiphilium, Gammproteobacteria) were detected in the $\left[{ }^{13} \mathrm{C}\right]-\mathrm{CH}_{3} \mathrm{OH}$-amended treatment only (OTU14 $\left.{ }_{\mathrm{mdh}}\right)$ (Figs. 3c and S5). We hypothesize that OTU14 ${ }_{\text {mdh }}$ corresponds to a methanol utilizer, not a $\mathrm{CH}_{3} \mathrm{Cl}$ utilizer, also because only methanol-utilizing strains are known in Acetobacteraceae $[43,44]$. In both $\left[{ }^{13} \mathrm{C}\right]-\mathrm{CH}_{3} \mathrm{Cl}$-amended treatments, OTU25 $5_{\text {mdh }}$ was dominant, whereas in both $\left[{ }^{13} \mathrm{C}\right]-\mathrm{CH}_{3} \mathrm{OH}$ amended treatments, OTU24 $4_{\text {mdh }}$ prevailed. Both OTUs correspond to Bradyrhizobium-like xoxF genes.

\section{Key Bacteria of the $\mathrm{CH}_{3} \mathrm{Cl}$ sink in the investigated top soil}

At first glance, bacterial taxa suggested to be associated with utilization of $\mathrm{CH}_{3} \mathrm{Cl}$ differ depending on which of the three investigated gene biomarkers in the $\left[{ }^{13} \mathrm{C}\right]-\mathrm{CH}_{3} \mathrm{Cl}$ SIP experiment is considered (Fig. 3, Tables 3 and 4). However, consideration of the labeling proportion (LP) of ${ }^{13} \mathrm{C}$-labeled OTUs (Fig. 3) allows to refine the analysis. A high LP suggests strong ${ }^{13} \mathrm{C}$-labeling, hinting at predominant transformation of the ${ }^{13} \mathrm{C}$ labeled-substrate by Alphaproteobacteria. In support of this, the taxonomic 16S rRNA gene biomarker indeed suggests that this class, and in particular strains closely related to Methylovirgula within the Beijerinckiaceae family, includes a major part of the primary utilizers of amended $\left[{ }^{13} \mathrm{C}\right]-\mathrm{CH}_{3} \mathrm{Cl}$ soils (Figs. 3a, S4, S6). Beyond that, the LP analysis approach also allowed to identify Actinobacteria of the genus Kineospora as potential novel key $\left[{ }^{13} \mathrm{C}\right]-\mathrm{CH}_{3} \mathrm{Cl}$ degraders (Figs. 3a, S4, Table S3).

\section{Discussion}

We show in this study that the oxic compartment of top soil was the main sink for $\mathrm{CH}_{3} \mathrm{Cl}$ in the investigated forest soil, and that this degradation process was primarily biotic, in agreement with an early exploratory study of $\mathrm{CH}_{3} \mathrm{Cl}$ dissipation in various environments [27]. We performed a detailed study of potential $\mathrm{CH}_{3} \mathrm{Cl}$ degraders in top soil, and focused on oxic conditions, since anoxic incubations did not show evidence for $\mathrm{CH}_{3} \mathrm{Cl}$ consumption, as expected given that strict anaerobes are not frequently abundant in oxic soils [45].
Table 3 Number of filtered sequences obtained from heavy DNA fractions

\begin{tabular}{lcrc}
\hline Treatment & 16S rRNA gene & cmuA & mxaF/xoxF \\
\hline$\left[{ }^{13} \mathrm{C}\right]-\mathrm{CH}_{3} \mathrm{Cl}$ & 46110 & 4282 & 786 \\
{$\left[{ }^{13} \mathrm{C}\right]-\mathrm{CH}_{3} \mathrm{Cl}$ and $\mathrm{CH}_{3} \mathrm{OH}$} & 178042 & 3778 & 1534 \\
$\mathrm{CH}_{3} \mathrm{Cl}$ and $\left[{ }^{13} \mathrm{C}\right]-\mathrm{CH}_{3} \mathrm{OH}$ & 76690 & 614 & 918 \\
{$\left[{ }^{13} \mathrm{C}\right]-\mathrm{CH}_{3} \mathrm{OH}$} & 98332 & 1886 & 588 \\
$\mathrm{CH}_{3} \mathrm{Cl}$ & 72522 & 370 & 2616 \\
$\mathrm{CH}_{3} \mathrm{Cl}$ and $\mathrm{CH}_{3} \mathrm{OH}$ & 47236 & 922 & 862 \\
$\mathrm{CH}_{3} \mathrm{OH}$ & 90822 & 246 & 2946 \\
Unamended control & 100032 & 184 & 2710 \\
\hline
\end{tabular}

See Table S1 for further information

Table 4 Diversity indices for 16S rRNA gene OTUs obtained from heavy and light fractions of SIP experiment

\begin{tabular}{llllc}
\hline Microcosm & $\begin{array}{l}\text { SIP } \\
\text { fraction }\end{array}$ & Sobs $^{\mathrm{a}}$ & $\begin{array}{l}\text { Shannon } \\
\text { index }\end{array}$ & $\begin{array}{l}\text { Simpson } \\
\text { diversity }\end{array}$ \\
\hline$\left[{ }^{13} \mathrm{C}\right]-\mathrm{CH}_{3} \mathrm{Cl}$ & $\mathrm{H}$ & 1762 & 5.95 & 44 \\
& $\mathrm{~L}$ & 2870 & 7.82 & 223 \\
{$\left[{ }^{13} \mathrm{C}\right]-\mathrm{CH}_{3} \mathrm{Cl}$ and } & $\mathrm{H}$ & 1629 & 6.11 & 36 \\
$\mathrm{CH}_{3} \mathrm{OH}$ & $\mathrm{L}$ & 3150 & 7.55 & 354 \\
$\mathrm{CH}_{3} \mathrm{Cl}$ and $\left[{ }^{13} \mathrm{C}\right]-$ & $\mathrm{H}$ & 1566 & 6.52 & 120 \\
$\mathrm{CH}_{3} \mathrm{OH}$ & $\mathrm{L}$ & 3062 & 7.86 & 283 \\
{$\left[{ }^{13} \mathrm{C}\right]-\mathrm{CH}{ }_{3} \mathrm{OH}$} & $\mathrm{H}$ & 1215 & 4.58 & 7 \\
& $\mathrm{~L}$ & 3148 & 7.40 & 322 \\
Unamended & $\mathrm{H}$ & 1804 & 6.45 & 102 \\
control & $\mathrm{L}$ & 2904 & 7.39 & 217 \\
\hline
\end{tabular}

${ }^{\mathrm{a}}$ Calculated at the $98 \%$ sequence identity level. See Materials and Methods for definitions. Simpson diversity is considered a conservative measure of the effective number of phylotypes [63]

\section{Potential bacterial degraders of $\mathrm{CH}_{3} \mathrm{Cl}$ in forest top soil are phylogenetically distinct from known $\mathrm{CH}_{3} \mathrm{Cl}$ - utilizing isolates}

Alphaproteobacteria (i.e., Beijerinckiaceae), and Actinobacteria (i.e., Kineosporaceae) likely represent key $\mathrm{CH}_{3} \mathrm{Cl}$ degraders in the investigated forest soil (Fig. 3a). The phylogenetic affiliation of these $\mathrm{CH}_{3} \mathrm{Cl}$ utilizers was only distantly related to known $\mathrm{CH}_{3} \mathrm{Cl}$ degraders and thus a novel finding. Moreover, metabolically active Actinobacteria show only limited sequence identity with the only known $\mathrm{CH}_{3} \mathrm{Cl}$-degrading isolate of this phylum, Nocardioidia sp. strain SAC-4 [27] (Fig. S4). In contrast, almost all soil $\mathrm{CH}_{3} \mathrm{Cl}$-degrading isolates known so far are affiliated with only a few genera of Alphaproteobacteria $[15,18,29,30]$, and are phylogenetically distinct from the key genus associated with $\mathrm{CH}_{3} \mathrm{Cl}$ degradation in our study (Methylovirgula, family Beijerinckiaceae). In addition, members of the candidate division Cand. Saccharibacteria 
(syn. TM7) were also ${ }^{13} \mathrm{C}$-labeled in our experiments. Physiological knowledge within this division is limited, and methylotrophy unreported to date [40, 46]. Since crosslabeling via ${ }^{13} \mathrm{CO}_{2}$ cannot be fully ruled out in our experimental setup due to the long incubation period, further efforts will be required to confirm that this phylum indeed includes methylotrophs able to degrade $\mathrm{CH}_{3} \mathrm{Cl}$.

\section{Low diversity of the $\mathrm{CmuA}$ biomarker and potential horizontal gene transfer of $\mathrm{cmu}$ genes to Beijerinckiaceae}

Amplicons of $c m u A$ retrieved from ${ }^{13} \mathrm{C}$-labeled DNA were most closely similar to the cmuA gene of Methylobacterium extorquens $\mathrm{CM} 4$ in both $\left[{ }^{13} \mathrm{C}\right]-\mathrm{CH}_{3} \mathrm{Cl}$ and $\left[{ }^{13} \mathrm{C}\right]-\mathrm{CH}_{3} \mathrm{OH}$ treatments, despite the fact that newly designed стиA primers cover a broader diversity of known $с т и A$ sequences than previous ones (Fig. S7). However, abundance of Methylobacteriaceae in 16S rRNA gene datasets was $<1 \%$ (data not shown), and no OTU affiliated to this family was defined as ${ }^{13} \mathrm{C}$-labeled with the applied criteria. Notably, Beijerinckiaceae was the key family associated with $\mathrm{CH}_{3} \mathrm{Cl}$ degradation based on the 16S rRNA gene biomarker. This may suggest that $\mathrm{CH}_{3} \mathrm{Cl}$-degraders from Beijerinckiaceae use another $\mathrm{CH}_{3} \mathrm{Cl}$ degradation pathway than the $\mathrm{cmu}$ pathway, or that they possess a стиA gene that escapes detection with the used primers. Alternatively, such degraders may have acquired a known $с m и A$ gene by horizontal gene transfer. Indeed, the $с т и$ pathway is plasmid-borne in M. extorquens CM4 [47], and further experimental [48] as well as sequence-based [13] evidence for horizontal transfer of the capacity for chloromethane degradation is also available.

\section{Evidence for novel $\mathrm{CH}_{3} \mathrm{Cl}$ degraders based on mxaF/ xoxF}

Whereas $m x a F$ genes had been detected in a previous study of the same soil with canonical primers [22] (Fig. S5), mainly $x o x F$ sequences were retrieved here with newly designed primers that detect both $m x a F$ and $x o x F$ (Fig. S5, Supplemental Information). Of the detected 25 mxaF/xoxF OTUs, only three OTUs, most similar to $x o x F$ genes found in Bradyrhizobium and Sinorhizobium genomes, dominated microcosms irrespectively of the performed treatment (Fig. 3c). Worthy of note, growth with $\mathrm{CH}_{3} \mathrm{Cl}$ has not been reported to date for representatives of these genera [23, 49, 50]. In addition, xoxF genes similar to those of Methylobacterium were also ${ }^{13} \mathrm{C}$-labeled upon $\left[{ }^{13} \mathrm{C}\right]-\mathrm{CH}_{3} \mathrm{Cl}$ amendment. Although some cross-feeding of ${ }^{13} \mathrm{CO}_{2}$ cannot be entirely excluded since Bradyrhizobium, Sinorhizobium, and Methylobacterium can assimilate $\mathrm{CO}_{2}[49,51]$, this possibility was minimized by regular exchange of the gas phase to remove formed $\mathrm{CO}_{2}$. $16 \mathrm{~S}$ rRNA gene OTU analysis indicated members of Beijerinckiceae as main alphaproteobacterial $\mathrm{CH}_{3} \mathrm{Cl}$ degraders (Fig. 3a). Basing on phylogenetic analysis (Fig. S5), the major ${ }^{13} \mathrm{C}$-labeled $x o x F$ OTUs appear quite distinct from known $x o x F$ genes of Beijerinckiceae Sinorhizobium and Bradyrhizobium. Hence, we hypothesize that OTU24 $4_{\text {mdh }}$ and OTU25 mdh represent hitherto unknown $x o x F$ genes in Beijerinckiaceae, or that used primers discriminated against the genotype of Beijerinckiaceae. A XoxF-type MDH might be advantageous as it directly leads to formate, avoiding the more toxic formaldehyde produced by MxaFI-type MDH [52].

\section{Consumption of $\mathrm{CH}_{3} \mathrm{OH}$ by $\mathrm{CH}_{3} \mathrm{Cl}$ degraders and implications for the $\mathrm{CH}_{3} \mathrm{Cl}$ sink in soil}

Beijerinckiaceae were newly identified here as novel potential $\mathrm{CH}_{3} \mathrm{Cl}$ and also $\mathrm{CH}_{3} \mathrm{OH}$ utilizers. The latter finding agrees well with a previous study on the microbial methanol sink in the same soil [22]. None of the methylotrophic Beijerinckiaceae characterized so far utilize methyl halides [53]. Beijerinckiacea also comprise typical methanotrophs [54], and one such isolate was shown to transform $\mathrm{CH}_{3} \mathrm{Cl}$ under laboratory conditions, but not to grow with this compound [55, 56]. Basing on the functional gene marker pmoA (encoding the beta-subunit of particulate methane monooxygenase), representatives of the uncultivated upland soil cluster $\alpha$ taxon represented the most abundant group of methanotrophs in Steigerwald forest soil. This pmoA type, however, is phylogenetically distinct from pmoA of Beijerinckiaceae [32]. However, a recent study suggest that USC $\alpha$ is indeed a member of Beijerinckiceae [57]. Thus, we presently cannot rule out that methanotrophs were not involved in the observed $\mathrm{CH}_{3} \mathrm{Cl}$ sink activity in Steigerwald forest soil.

The presence of $\mathrm{CH}_{3} \mathrm{OH}$ as an alternative methylotrophic growth substrate supports the notion of enhanced assimilation of carbon from $\mathrm{CH}_{3} \mathrm{Cl}$ by Beijerinckiaceae during $\mathrm{CH}_{3} \mathrm{OH}$-driven growth. This idea is supported by the observed high labeling percentages in combined substrate amendments with $\mathrm{CH}_{3} \mathrm{OH}$ and $\left[{ }^{13} \mathrm{C}\right]-\mathrm{CH}_{3} \mathrm{Cl}$ (Fig. 3). Similarly, the reverse combined amendment of unlabeled $\mathrm{CH}_{3} \mathrm{OH}$ with $\left[{ }^{13} \mathrm{C}\right]-\mathrm{CH}_{3} \mathrm{Cl}$ led to increased mineralization of $\left[{ }^{13} \mathrm{C}\right]-\mathrm{CH}_{3} \mathrm{Cl}$ (Fig. S1). Taken together, these findings suggest that activity and growth of soil microorganisms that define the bacterial $\mathrm{CH}_{3} \mathrm{Cl}$ sink in the investigated soil strongly depend on availability of $\mathrm{CH}_{3} \mathrm{OH}$.

Many methylotrophs can simultaneously utilize several one-carbon compounds [58]. This is likely a selective advantage in natural environments when availability of potential substrates is variable and often limiting. As shown in a previous study on the same soil, Beijerinckiaceae can be either methylotrophic or non-methylotrophic [22]. On 
the basis of the data reported here, we suggest that key $\mathrm{CH}_{3} \mathrm{Cl}$ degraders in soil may be capable of assimilating several one-carbon substrates to optimize their growth. Such a metabolic lifestyle is likely to be of advantage in order to compete with other aerobes in the complex top soil environment, and suggests that the microbial $\mathrm{CH}_{3} \mathrm{Cl}$ sink is linked to the availability of other key carbon sources in soil such as $\mathrm{CH}_{3} \mathrm{OH}$.

\section{Conclusions}

Our study provides a first deep coverage exploration of bacterial diversity functionally linked with the $\mathrm{CH}_{3} \mathrm{Cl}$ sink in soil. It has revealed that $\mathrm{CH}_{3} \mathrm{Cl}$ consumption in forest soil may be driven by alternative carbon sources such as $\mathrm{CH}_{3} \mathrm{OH}$. It also uncovered new taxa associated with $\mathrm{CH}_{3} \mathrm{Cl}$ degradation, including genera of Alphaproteobacteria and Actinobacteria that had not yet been identified in the context of previous SIP experiments with $\mathrm{CH}_{3} \mathrm{Cl}$, and for which no isolates are yet available. The used $\mathrm{CH}_{3} \mathrm{Cl}$ concentrations, which are much higher than those encountered in the troposphere, might have harmed some bacteria that cannot grow with $1 \% \mathrm{CH}_{3} \mathrm{Cl}$. However, we focused in the study on those soil bacteria that can deal with these concentrations and degraded it. We are aware that the used SIP approach might have been biased by label transfer. However, the low limit of detection of DNA SIP combined with the very conservative approach chosen to identify potential chloromethane degraders, only strongly-labeled microorganisms were identified, which maximizes the likelihood that they were directly labeled from amended labeled chloromethane and not through crossfeeding. Taxa corresponding to cultivated model $\mathrm{CH}_{3} \mathrm{Cl}$ degraders, such as Methylobacterium extorquens $\mathrm{CM} 4$, were not relevant for $\mathrm{CH}_{3} \mathrm{Cl}$ degradation in the investigated forest top soil. Thus, cultivation of new isolates requires future efforts to improve coverage of existing diversity chloromethane degraders by isolates. Detection of стиA genes closely similar to those of such strains (>99\%) suggests that horizontal transfer of the ability to degrade $\mathrm{CH}_{3} \mathrm{Cl}$ is an important aspect of the $\mathrm{CH}_{3} \mathrm{Cl}$ sink in soil. Our study also suggests that methylotrophs in top soil may have a competitive advantage over non-methylotrophs by their ability to utilize diverse one-carbon substrates simultaneously. Testing this hypothesis, and addressing alternative metabolic strategies of $\mathrm{CH}_{3} \mathrm{Cl}$ degradation in soil, will be the topic of future investigations.

Acknowledgements $\mathrm{PC}$ was funded through a PhD grant from Région Alsace (France) and the Deutsche Forschungsgemeinschaft (Germany). LB was supported by the French Agence Nationale de la Recheche ANR (ANR-14-CE35-0005-01). MM was financed through the Deutsche Forschungsgemeinschaft DFG (Ko2912/5-1 and
Ko2912/10-1). The Deutsche Akademischer Austauschdienst (DAAD) program PROCOPE funded travel expenses. We thank Y. LouhichiJelail for technical assistance in performing PCR amplifications, and H.L. Drake and M.A. Horn for hosting the project at the Department of Ecological Microbiology of the University of Bayreuth (Germany).

\section{Compliance with ethical standards}

Conflict of interest The authors declare that they have no conflict of interest.

Open Access This article is licensed under a Creative Commons Attribution 4.0 International License, which permits use, sharing, adaptation, distribution and reproduction in any medium or format, as long as you give appropriate credit to the original author(s) and the source, provide a link to the Creative Commons license, and indicate if changes were made. The images or other third party material in this article are included in the article's Creative Commons license, unless indicated otherwise in a credit line to the material. If material is not included in the article's Creative Commons license and your intended use is not permitted by statutory regulation or exceeds the permitted use, you will need to obtain permission directly from the copyright holder. To view a copy of this license, visit http://creativecommons. org/licenses/by/4.0/.

\section{References}

1. Harper DB, Hamilton JTG, Ducrocq V, Kennedy JT, Downey A, Kalin RM. The distinctive isotopic signature of plant-derived chloromethane: possible application in constraining the atmospheric chloromethane budget. Chemosphere. 2003;52:433-6.

2. Tsai W-T (2017). Fate of chloromethanes in the atmospheric environment: implications for human health, ozone formation and depletion, and global warming impacts. Toxics. https://doi.org/10. 3390/toxics5040023.

3. Carpenter LJ, Reimann S (2014). Ozone-depleting substances (ODSs) and other gases of interest to the Montreal protocol. In: World Meteorological Organization (ed). Scientific Assessment of Ozone Depletion: 2014, Global Ozone Research and Monitoring Project. World Meteorological Organization: Geneva.

4. Xiao X, Prinn RG, Fraser PJ, Simmonds PG, Weiss RF, O'Doherty S, et al. Optimal estimation of the surface fluxes of methyl chloride using a 3-D global chemical transport model. Atmos Chem Phys. 2010;10:5515-33.

5. Harper DB. The global chloromethane cycle: biosynthesis, biodegradation and metabolic role. Nat Prod Rep. 2000;17:337-48.

6. Keppler F, Harper DB, Röckmann T, Moore RM, Hamilton JTG. New insight into the atmospheric chloromethane budget gained using stable carbon isotope ratios. Atmos Chem Phys. 2005;5:2403-11.

7. Schäfer H, Miller LG, Oremland RS, Murrell JC. Bacterial cycling of methyl halides. Adv Appl Microbiol. 2007;61:307-46.

8. Keppler F, Kalin RM, Harper DB, McRoberts WC, Hamilton JTG. Carbon isotope anomaly in the major plant $\mathrm{C}_{1}$ pool and its global biogeochemical implications. Biogeosciences. 2004;1: 123-31.

9. McRoberts WC, Keppler F, Harper DB, Hamilton JTG. Seasonal changes in chlorine and methoxyl content of leaves of deciduous trees and their impact on release of chloromethane and methanol at elevated temperatures. Environ Chem. 2015;12:426-37.

10. Rhew RC, Østergaard L, Saltzman ES, Yanofsky MF. Genetic control of methyl halide production in Arabidopsis. Curr Biol. 2003;13:1809-13. 
11. Yoshida Y. A three-dimensional global model study of atmospheric methyl chloride budget and distributions. J Geophys Res. 2004;109:D24309.

12. Redeker KR, Kalin RM. Methyl chloride isotopic signatures from Irish forest soils and a comparison between abiotic and biogenic methyl halide soil fluxes. Glob Change Biol. 2012;18:1453-67.

13. Nadalig T, Greule M, Bringel F, Keppler F, Vuilleumier S. Probing the diversity of chloromethane-degrading bacteria by comparative genomics and isotopic fractionation. Front Microbiol. 2014;5:523.

14. IPCC (2013). Climate Change 2013: The Physical Science Basis. Contribution of working group I to the fifth assessment report of the intergovernmental panel on climate change. Cambridge, and New York, NY.

15. Borodina E, Cox MJ, McDonald IR, Murrell JC. Use of DNAstable isotope probing and functional gene probes to investigate the diversity of methyl chloride-utilizing bacteria in soil. Environ Microbiol. 2005;7:1318-28.

16. Farhan Ul Haque M, Besaury L, Nadalig T, Bringel F, Mutterer J, Schaller $\mathrm{H}$, et al. Correlated production and consumption of chloromethane in the Arabidopsis thaliana phyllosphere. Sci Rep. 2017;7:17589.

17. McDonald IR, Doronina NV, Trotsenko YA, McAnulla C, Murrell JC. Hyphomicrobium chloromethanicum sp. nov. and Methylobacterium chloromethanicum sp. nov., chloromethaneutilizing bacteria isolated from a polluted environment. Int J Syst Evol Microbiol. 2001;51:119-22.

18. Miller LG, Warner KL, Baesman SM, Oremland RS, McDonald IR, Radajewski S, et al. Degradation of methyl bromide and methyl chloride in soil microcosms: use of stable $\mathrm{C}$ isotope fractionation and stable isotope probing to identify reactions and the responsible microorganisms. Geochim Cosmochim Acta. 2004;68:3271-83.

19. Shorter J, Kolb C, Crill P. Rapid degradation of atmospheric methyl bromide in soil. Nature. 1995;377:717-9.

20. Yoshida Y, Wang YH, Shim C, Cunnold D, Blake DR, Dutton GS. Inverse modeling of the global methyl chloride sources. J Geophys Res Atmos. 2006;111:D16307.

21. Chaignaud P, Maucourt B, Weiman M, Alberti A, Kolb S, Cruveiller $\mathrm{S}$, et al. Genomic and transcriptomic analysis of growthsupporting dehalogenation of chlorinated methanes in Methylobacterium. Front Microbiol. 2017;8:1600.

22. Morawe M, Hoeke H, Wissenbach DK, Lentendu G, Wubet T, Kröber E, et al. Acidotolerant bacteria and fungi as a sink of methanol-derived carbon in a deciduous forest soil. Front Microbiol. 2017;8:1361.

23. Kolb S. Aerobic methanol-oxidizing bacteria in soil. FEMS Microbiol Lett. 2009;300:1-10.

24. Kolb S, Stacheter A. Prerequisites for amplicon pyrosequencing of microbial methanol utilizers in the environment. Front Microbiol. 2013;4:268.

25. Coulter C, Hamilton JTG, McRoberts WC, Kulakov L, Larkin MJ, Harper DB. Halomethane: bisulfide/halide ion methyltransferase, an unusual corrinoid enzyme of environmental significance isolated from an aerobic methylotroph using chloromethane as the sole carbon source. Appl Environ Microbiol. 1999;65:4301-12.

26. Doronina NV, Sokolov AP, Trotsenko YA. Isolation and initial characterization of aerobic chloromethane-utilizing bacteria. FEMS Microbiol Lett. 1996;142:179-83.

27. McAnulla C, McDonald IR, Murrell JC. Methyl chloride utilising bacteria are ubiquitous in the natural environment. FEMS Microbiol Lett. 2001a;201:151-5.

28. McAnulla C, Woodall CA, McDonald IR, Studer A, Vuilleumier $\mathrm{S}$, Leisinger T, et al. Chloromethane utilization gene cluster from Hyphomicrobium chloromethanicum strain $\mathrm{CM}^{\mathrm{T}}$ and development of functional gene probes to detect halomethanedegrading bacteria. Appl Environ Microbiol. 2001b;67:307-16.

29. Nadalig T, Farhan Ul Haque M, Roselli S, Schaller H, Bringel F, Vuilleumier S. Detection and isolation of chloromethanedegrading bacteria from the Arabidopsis thaliana phyllosphere, and characterization of chloromethane utilisation genes. FEMS Microbiol Ecol. 2011;77:438-48.

30. Schäfer H, McDonald IR, Nightingale PD, Murrell JC. Evidence for the presence of a $\mathrm{CmuA}$ methyltransferase pathway in novel marine methyl halide-oxidizing bacteria. Environ Microbiol. 2005;7:839-52.

31. Degelmann DM, Borken W, Kolb S. Methane oxidation kinetics differ in European beech and Norway spruce soils. Eur J Soil Sci. 2009;60:499-506.

32. Degelmann DM, Borken W, Drake HL, Kolb S. Different atmospheric methane-oxidizing communities in European beech and Norway spruce soils. Appl Environ Microbiol. 2010;76: 3228-35.

33. Griffiths RI, Whiteley AS, O'Donnell AG, Bailey MJ. Rapid method for coextraction of DNA and RNA from natural environments for analysis of ribosomal DNA- and rRNA-based microbial community composition. Appl Environ Microbiol. 2000;66:5488-91.

34. Neufeld JD, Vohra J, Dumont MG, Lueders T, Manefield M, Friedrich MW, et al. DNA stable-isotope probing. Nat Prot. 2007;2:860-6.

35. Kozich JJ, Westcott SL, Baxter NT, Highlander SK, Schloss PD. Development of a dual-index sequencing strategy and curation pipeline for analyzing amplicon sequence data on the MiSeq Illumina sequencing platform. Appl Environ Microbiol. 2013;79: 5112-20.

36. Edgar RC, Haas BJ, Clemente JC, Quince C, Knight R. UCHIME improves sensitivity and speed of chimera detection. Bioinformatics. 2011;27:2194-200.

37. Edgar RC. Search and clustering orders of magnitude faster than BLAST. Bioinformatics. 2010;26:2460-1.

38. Stacheter A, Noll M, Lee CK, Selzer M, Glowik B, Ebertsch L, et al. Methanol oxidation by temperate soils and environmental determinants of associated methylotrophs. ISME J. 2013;7:1051-64.

39. Dallinger A, Horn MA. Agricultural soil and drilosphere as reservoirs of new and unusual assimilators of 2,4-dichlorophenol carbon. Environ Microbiol. 2014;16:84-100.

40. Ferrari B, Winsley T, Ji M, Neilan B. Insights into the distribution and abundance of the ubiquitous Candidatus Saccharibacteria phylum following tag pyrosequencing. Sci Rep. 2014;4:3957.

41. Keltjens JT, Pol A, Reimann J, Op den Camp HJM. PQQdependent methanol dehydrogenases: rare-earth elements make a difference. Appl Microbiol Biotechnol. 2014;98:6163-83.

42. Taubert M, Grob C, Howat AM, Burns OJ, Dixon JL, Chen Y, et al. $X o x F$ encoding an alternative methanol dehydrogenase is widespread in coastal marine environments. Environ Microbiol. 2015;17:3937-48.

43. Greenberg D, Porcella S, Stock F, Wong A, Conville P, PR M. Granulibacter bethesdensis gen. nov., sp. nov., a distinctive pathogenic acetic acid bacterium in the family Acetobacteraceae. Int J Syst Evol Microbiol. 2005;56:2609-16.

44. Urakami T, Tamaoka J, Suzuki K-I, Komagata K. Acidomonas gen. nov., incorporating Acetobacter methanolicus as Acidomonas methanolica comb. nov. Int J Syst Evol Microbiol. 1989;39: $50-5$.

45. Traunecker J, Preuss A, Diekert G. Isolation and characterization of a methyl chloride utilizing, strictly anaerobic bacterium. Arch Microbiol. 1991;156:416-21.

46. He XS, McLean JS, Edlund A, Yooseph S, Hall AP, Liu SY, et al. Cultivation of a human-associated TM7 phylotype reveals a 
reduced genome and epibiotic parasitic lifestyle. Proc Natl Acad Sci USA. 2015;112:244-9.

47. Roselli S, Nadalig T, Vuilleumier S, Bringel F. The $380 \mathrm{~kb}$ pCMU01 plasmid encodes chloromethane utilization genes and redundant genes for vitamin $\mathrm{B}_{12}$ - and tetrahydrofolate-dependent chloromethane metabolism in Methylobacterium extorquens CM4: a proteomic and bioinformatics study. PloS One. 2013;8:e56598.

48. Michener JK, Vuilleumier S, Bringel F, Marx CJ. Transfer of a catabolic pathway for chloromethane in Methylobacterium strains highlights different limitations for growth with chloromethane or with dichloromethane. Front Microbiol. 2016;7:1116.

49. de Souza J, Alves L, Mello Varani A, de Macedo Lemos E. The Family Bradyrhizobiaceae. In: Rosenberg E, DeLong E, Lory S, Stackebrandt E, Thompson F, (eds). The prokaryotes-alphaproteobacteria and betaproteobacteria. New York, NY: Springer; 2013. p. $135-54$.

50. Sudtachat N, Ito N, Itakura M, Masuda S, Eda S, Mitsui H, et al. Aerobic vanillate degradation and $\mathrm{C} 1$ compound metabolism in Bradyrhizobium japonicum. Appl Environ Microbiol. 2009; 75:5012-17.

51. Masuda S, Eda S, Sugawara C, Mitsui H, Minamisawa K. The $c b b L$ gene is required for thiosulfate-dependent autotrophic growth of Bradyrhizobium japonicum. Microb Environ. 2010; $25: 220-3$.

52. Masuda S, Suzuki Y, Fuijtani Y, Mitsui R, Nakagawa T, Shintani M, Tani A. Lanthanide-regulation of methylotrophy in Methylobacterium aquaticum strain 22A. mSphere. 2018;3: e00462-17.

53. Marin I, Arahal D. The Family Beijerinckiaceae. In: Rosenberg E, DeLong E, Lory S, Stackebrandt E, Thompson F, (eds). The prokaryotes-alphaproteobacteria and betaproteobacteria. New York, NY: Springer; 2013. p. 115-33.

54. Knief C. Diversity and habitat preferences of cultivated and uncultivated aerobic Methanotrophic bacteria evaluated based on pmoA as molecular marker. Front Microbiol. 2015;6:1346.
55. Han JI, Semrau JD. Chloromethane stimulates growth of Methylomicrobium album BG8 on methanol. FEMS Microbiol Lett. 2000;187:77-81.

56. Stirling DI, Dalton H. Properties of the methane mono-oxygenase from extracts of Methylosinus trichosporium OB3b and evidence for its similarity to the enzyme from Methylococcus capsulatus (Bath). Eur J Biochem. 1979;96:205-12.

57. Pratscher J, Vollmers J, Wiegand S, Dumont MG, Kaster A-K. Unravelling the identity, metabolic potential and global biogeography of the atmospheric methane-oxidizing upland soil cluster $\alpha$. Environ Microbiol. 2018;20:1016-29.

58. Halsey KH, Carter AE, Giovannoni SJ. Synergistic metabolism of a broad range of $\mathrm{C} 1$ compounds in the marine methylotrophic bacterium HTCC2181. Environ Microbiol. 2012;14: $630-40$.

59. Tamura K, Nei M. Estimation of the number of nucleotide substitutions in the control region of mitochondrial DNA in humans and chimpanzees. Mol Biol Evol. 1993;10:512-26.

60. Muyzer G, Brinkhoff T, Nuebel U, Santegoeds C, Schaefer H, Waver C. Denaturing gradient gel electrophoresis (DGGE) in microbial ecology. In: Akkermans A, van Elsas J, de Bruijn F, (eds). Molecular microbial ecology manual. Dordrecht: Kluwer Academic Publishers; 1998. p. 1-27.

61. Herlemann DPR, Labrenz M, Jurgens K, Bertilsson S, Waniek JJ, Andersson AF. Transitions in bacterial communities along the $2000 \mathrm{~km}$ salinity gradient of the Baltic Sea. ISME J. 2011;5:1571-9.

62. Zheng L, Gibbs MJ, Rodoni BC. Quantitative PCR measurements of the effects of introducing inosines into primers provides guidelines for improved degenerate primer design. J Virol Methods. 2008;153:97-103.

63. Haegeman B, Sen B, Godon J-J, Hamelin J. Only Simpson diversity can be estimated accurately from microbial community fingerprints. Microb Ecol. 2014;68:169-72. 